\title{
A Comparision of the Effects of Aloe Barbadensis and Allium Sativum Extracts on Paracetamol - Induced Hepatotoxicity In Albino Rats
}

\author{
${ }^{1}$ L. N.; Ebenyi, ${ }^{2}$ U. A.; Ibiam, ${ }^{3}$ R. O.; Inya Agha , ${ }^{4}$ M. E.; Ogbanshi* and \\ ${ }^{5}$ C.A.; Uhuo \\ 1. Department of Biotechnology, Ebonyi State University Abakaliki, \\ 2. Department of Biochemistry, Ebonyi State University, Abakaliki, P.M.B 05. \\ 3: Department of Biology, Ebonyi State University, Abakaliki, P.M.B 05, Abakaliki.
}

\begin{abstract}
A Comparison of the influence of ethanol extracts of Aloe barbadensis and Allium sativum on paracetamol-induced hepatotoxicity were studied invivo using rat model. A total of 32 rats were used for the study using extracts biochemical analysis. The rats were grouped into four with four rats in each group. Group A was the control, Group B received paracetamol over dose $(500 \mathrm{mg} / \mathrm{kg} / \mathrm{ml})$ without extracts and Group C received paracetamol over dose plus extract of Allium sativum at three different concentrations of 200, 400 and 800 ug//body weight. Group D also received paracetamol over dose plus extract of A. barbadensis at three different concentrations of 200, 400 and $800 \mathrm{ug} /$ body weight. The invivo studies, showed significant changes in biochemical parameters such as liver enzymes (AST, ALT and ALP) and Heamatological parameters (Total protein, albumin and Bilirubin).However, administration of the ethanol extracts caused a significant reversal $(p<0.05)$ of these effects in a concentration dependent manner. This work has demonstrated the hepatotoxicity of paracetamol and hepatoprotective effects of extracts of A. barbadensis and A. sativum .
\end{abstract}

Keywords: Paracetamol, Hepatotoxicity, Aloe barbadensis and Allium sativum extracts.

\section{Introduction}

Paracetamol, an analgesic and antipyretic agent, is a useful drug in the treatment of mild pain. This analgesic is one of the silent causes of liver damage due to its constant abuse. The metabolism of paracetamol is an excellent example of intoxication, because the metabolite $\mathrm{N}$-acetyl-p-benzo-quinone imines, abbreviated as NAPQI is the primary cause of toxicity rather than paracetamol itself this metabolite NAPQI reacts with proteins and nucleic acids to produce toxic free radicals. These unconjugated free radicals can cause cell damage through mechanisms of covalent binding and lipid peroxidation with subsequent tissue injury (Yoshiki, Y. and Okubo, K. 1995). . The mechanism involves a process whereby unsaturated lipids are oxidized to form free radical oxygen species and other toxic by- products that can be harmful to the host system [1].

Polyunsaturated lipids (in the cell) are especially susceptible to this type of damage. When in an oxidizing environment, they react to form lipid peroxides. The role of free radical reactions in disease pathology is well established. Considerable attention has recently been focused on the inter- relationships of lipid peroxidation processes, free- radical- related reactions and the development of a variety of pathological states [1]. It is well established that lipid peroxidation is the deleterious result of free radical reactions leading to disruption of biomembranes and subsequent dysfunction of cells and tissues [1]. Therefore lipid peroxidation is a crucial step in the pathogenesis of free radical related disease states, including inflammatory injuries, arteriosclerosis, rheumatoid arthritis, gastrointestinal diseases, cardiovascular, nervous system and other diseases as well as toxicity of many xenobiotic [8].

In recent years, there has been a global trend towards the use of natural phytochemicals present in herbs and functional foods as antioxidants because polyphenols isolated from them have potential therapeutic role in the prevention and treatment of many human disease related to oxidative stress [8-10]. Among the species of medicinal plants and spices, which are being used for various therapeutic purposes, Allium sativum and Aloe barbadensis are very prominent.

Aloe barbadensis often called the miracle plant, the natural healer or the burn plant [17-13]. Aloe barbadensis has been around for over 4000 years during which its amazing medicinal potentials have benefited mankind tremendously. Aloe barbadensis commonly called Aloe is a succulent, thick, fleshy medicinal plant which contains many nutrient and chemical components like: vitamins, minerals amino acids, saponin, lignin, alkaloids and antraquinones [17]. The Aloins extracted from the leaves can be used to treat both internal and external wounds and burns like ulcer, cough, gastritis, diabetes, cancer, headaches, arthritis immune system deficiencies and many other conditions [4]. 


\section{Collection of Biological Materials}

\section{Materials And Methods}

The leaves of Aloe barbadensis (400g) and Allium sativum (200g) were purchased from Abakpa Market in Abakaliki, Ebonyi State.

32 albino rats were purchased from the University of Nigeria Nsukka Animal House and were acclimatized for 2 weeks in the Animal House of Biochemistry Department, Ebonyi State University, and Abakaliki.

\section{METHODS}

\section{Ethanolic Extraction of Plant Materials;}

\section{Cold extraction}

$400 \mathrm{~g}$ of Aloe barbadensis was collected washed, sliced, mashed gently with mortar and pistol and soaked in 400 $\mathrm{ml}$ of Ethanol (99\% BDH) for a period of 24 hours which turned out light green in coloration. Since Aloe barbadensis have thick leaves that can be difficult to dry, this method of extraction was used [14].

The residue was removed from the extract using filter paper and the extract evaporated at $50{ }^{\circ} \mathrm{C}$ using an oven until a gel like substance was formed.

\section{Preparation of Extracts}

$0.02 \mathrm{~g}, 0.04 \mathrm{~g}$ and $0.08 \mathrm{~g}$ of each of the extracts were weighed respectively and each diluted in $100 \mathrm{ml}$ of distilled water to form $200 \mu \mathrm{g} / \mathrm{ml}, 400 \mu \mathrm{g} / \mathrm{ml}$ and $800 \mu \mathrm{g} / \mathrm{ml}$ of the extracts, respectively.

\section{Administration of Paracetamol Overdose and Extracts.}

The first group A served as the control group; group B, C and D were used as test groups, each had 3 rats. Hepatotoxicity was induced by administering $500 \mathrm{mg}$ of paracetamol per $\mathrm{kg}$ rat. The control (group A) was fed with rat feed and water for 7 days. Group B was fed with rat feed, water and paracetamol orally at $500 \mathrm{mg} / \mathrm{kg} /$ day without any extract. Group C made up of 12 rats of 3 sub groups received paracetamol overdose plus extract of Aloe barbadensis at different concentrations of $200 \mu \mathrm{g} / \mathrm{ml}, 400 \mu \mathrm{g} / \mathrm{ml}$ and $800 \mu \mathrm{g} / \mathrm{ml}$.

\section{BIOCHEMICAL ANALYSIS}

After ( 7 days) administration period, all the animals were sacrificed. The rats were dissected and $5 \mathrm{ml}$ of blood drawn from the heart directly with aid of $5 \mathrm{ml}$ syringe. The blood was poured into test tubes, placed inside the centrifuge and centrifuged at $5000 \mathrm{rmp}$ for 10 minutes. The serum was then separated and used for assay of serum aspartate transaminases activity (AST), alanine transaminases activity (ALT) and serum alkaline phosphatase ALP using the method of [7]. Direct and total Bilirubin were measured using the method of [14].

Total protein was measured using the method of [15] while GSH was determined by the method of [5]

\section{STATISTICAL ANALYSIS}

Data for liver enzyme activity (AST, ALT,ALP) and serum protein level ( Total Protein, Albumin, Globulin,GSH and Blilrubin) were expressed as mean \pm SD and analyzed statistically using One Way Analysis of Variance (ANOVA).Statistical significance was fixed at $\mathrm{P}<0.05$.

\section{Extraction Yield Of Plant Matrials}

\section{Results}

Table 1: Extraction Yield of Allium sativum and Aloe barbadensis plant materials

\begin{tabular}{llll}
\hline Plants & Initial weight & Weight after evaporation & \% Yield \\
\hline Allium sativum & $200 \mathrm{~g}$ & $13.5 \mathrm{~g}$ & $6.8 \%$ \\
Aloe barbadensis & $400 \mathrm{~g}$ & $47.2 \mathrm{~g}$ & $11.8 \%$
\end{tabular}

Table2: Effect of ethanol extracts of Allium sativum and aloe barbadensis on biochemical parameters (AST, ALT and ALP) hematological parameters (bilirubin) on paracetamol-induced Hepatotoxicity in rats

\begin{tabular}{|c|c|c|c|c|c|c|}
\hline $\begin{array}{l}\text { GROU } \\
\text { P }\end{array}$ & TREATMENT & $\begin{array}{l}\text { CONCENTRAT } \\
\text { ION }\end{array}$ & $\begin{array}{l}\mathrm{AST} \\
(\mathrm{U} / \mathrm{mL})\end{array}$ & $\begin{array}{l}\text { ALT } \\
(\mathrm{U} / \mathrm{ml})\end{array}$ & $\begin{array}{l}\text { ALP } \\
(\mathrm{U} / \mathrm{ml})\end{array}$ & $\begin{array}{l}\text { BIIIRUBIN } \\
\text { Total Direct }\end{array}$ \\
\hline A & CONTROI & & $\begin{array}{l}37.96 \\
\pm 1.88\end{array}$ & $\begin{array}{l}21.71 \\
\pm 0.02\end{array}$ & $\begin{array}{l}89.23 \\
\pm 4.45\end{array}$ & $\begin{array}{ll}0.61 & 0.08 \\
\pm 0.02 & \pm 0.01\end{array}$ \\
\hline \multirow[t]{2}{*}{ B } & $\begin{array}{l}\text { PARACETAMOL } \\
\text { TREATED }\end{array}$ & & $123.60^{*}$ & $104.93 *$ & $200.57 *$ & $5.40 * 0.96 *$ \\
\hline & & & \pm 1.94 & \pm 1.83 & \pm 3.46 & $\pm 0.31=0.15$ \\
\hline \multirow[t]{10}{*}{ c } & $\begin{array}{l}\text { PARACETAMOL } \\
\text { + EXTRACT } 1 \\
\text { (Allium sativum) }\end{array}$ & $200 \mu \mathrm{g} / \mathrm{ml} \mathrm{C}_{1}$ & 86.65 & 84.02 & 188.18 & $430 \quad 0.70$ \\
\hline & & & \pm 2.22 & $=1.05$ & $=3,54$ & $=0.07=0.03$ \\
\hline & & $400 \mu \mathrm{g} / \mathrm{ml} \mathrm{C}$ & 66.81 & $\begin{array}{l}66.91 \\
-0.89\end{array}$ & 155.63 & $2.87 \quad 0.40$ \\
\hline & & $800_{\mu g} / \mathrm{mlC}^{2}$ & $\begin{array}{l} \pm 2.46 \\
50.11 * k\end{array}$ & $\begin{array}{l} \pm 0.89 \\
47.6 \%\end{array}$ & $\begin{array}{l} \pm 2.35 \\
131.41 * *\end{array}$ & $\begin{array}{l} \pm 0.48=0.08 \\
0.93 * 0.18^{*}\end{array}$ \\
\hline & & & \pm 1.07 & $=1.75$ & \pm 0.55 & $\pm 0.01=0.40$ \\
\hline & $\begin{array}{l}\text { PARACETAMOL } \\
+ \text { EXTRACT II } \\
\text { (Aloebarbadensis) }\end{array}$ & $200 \mu \mathrm{g} / \mathrm{mil} \mathrm{D}_{1}$ & 1038 & 90.79 & 192.56 & $4.85 \quad 0.81$ \\
\hline & & & $=1.75$ & \pm 2.75 & $=2.28$ & $\pm 0.14=1.01$ \\
\hline & & $400 \mu \Omega / \mathrm{ml} \mathrm{D}$ & 93.48 & 74.23 & 173.57 & 0.53 \\
\hline & & & \pm 0.74 & \pm 1.23 & $=1.48$ & $\pm 0.06 \pm 0.09$ \\
\hline & & $800 \mathrm{Mg} / \mathrm{mL}$ Di & $66.34^{* * *}$ & $5030^{* *}$ & $151.28^{* *}$ & $1.05 * * 030 * *$ \\
\hline
\end{tabular}

* Significant difference as compared with control, **Significant difference as compared with paracetamol. 
Table 3: Effect of ethanol extracts of Allium sativum and Aloe barbadensis on biochemical parameters (total protein, albumen, globulin and GSH) on paracetamol induced Hepatotoxicity in rats.

\begin{tabular}{|c|c|c|c|c|c|c|c|}
\hline GROUP & $\begin{array}{l}\text { TREATMEN } \\
\text { T }\end{array}$ & $\begin{array}{l}\text { CONCENTRATI } \\
\text { ON }\end{array}$ & $\begin{array}{l}\text { Total } \\
\text { protei } \\
\text { n }(g / 1)\end{array}$ & $\begin{array}{l}\text { Album } \\
\text { in }(g / 1)\end{array}$ & $\begin{array}{l}\text { Globuli } \\
n(E / 1)\end{array}$ & $\begin{array}{l}\text { GSH }(\mu \mathrm{g} / \mathrm{ml} \\
\text { of protein) }\end{array}$ & $\begin{array}{l}\mathrm{A} / \mathrm{G} \\
\text { Ratio }\end{array}$ \\
\hline \multirow[t]{2}{*}{ A } & Control & & 71.34 & 42.26 & 28.71 & 61.59 & 1,48 \\
\hline & & & \pm 1.73 & \pm 0.95 & \pm 0.08 & \pm 2.11 & \\
\hline B & $\begin{array}{l}\text { Paracetamol } \\
\text { treated }\end{array}$ & & $19.85 \%$ & $7.30^{\circ}$ & $12.55 \%$ & $32.42 *$ & $0.58 *$ \\
\hline & & & \pm 2.06 & \pm 2.92 & $\neq 1.21$ & \pm 1.30 & \\
\hline \multirow[t]{12}{*}{ C } & $\begin{array}{l}\text { Paracetamol + } \\
\text { extract } \\
1 \text { (Allium } \\
\text { sativum) }\end{array}$ & $200 \mu \mathrm{g} / \mathrm{ml} \mathrm{C} \mathrm{C}_{1}$ & 26.68 & 8.68 & 18.00 & 44.42 & 0.40 \\
\hline & & & $\neq 0.98$ & \pm 1.09 & $=0.91$ & \pm 1.30 & \\
\hline & & $400 \mu \mathrm{g} / \mathrm{ml} \mathrm{C}_{2}$ & 31.40 & 12.59 & 18.80 & 50.78 & 0.67 \\
\hline & & & \pm 1.71 & \pm 0.04 & \pm 0.07 & \pm 0.95 & \\
\hline & & $800 \mu \mathrm{gmlC}$ & $34.34 *$ & $19.10^{\circ}$ & $15.24 *$ & $54.66 *+$ & $1.25 *$ \\
\hline & & & $=0.05$ & \pm 0.05 & \pm 0.03 & \pm 1.11 & \\
\hline & $\begin{array}{l}\text { Paracetamol + } \\
\text { extract II } \\
\text { (Aloe } \\
\text { barbadensis) }\end{array}$ & $200 \mu \mathrm{g} / \mathrm{ml} \mathrm{D}_{1}$ & 22.60 & 6.68 & 15.92 & 33.56 & 0.42 \\
\hline & & & \pm 2.11 & \pm 1.90 & \pm 0.10 & \pm 4.00 & 0.10 \\
\hline & & $400 \mu \mathrm{g} / \mathrm{ml} \mathrm{D}_{2}$ & 29.72 & 8.44 & 21.28 & 48.28 & 0.40 \\
\hline & & & $=0.37$ & \pm 0.80 & \pm 0.34 & \pm 0.35 & \\
\hline & & $800 \mu g / \mathrm{ml} \mathrm{D}_{3}$ & $33.08 \%$ & $11.40=$ & $21.68 *$ & $50.75 \cdots$ & $0.53 *$ \\
\hline & & & \pm 0.67 & \pm 0.03 & \pm 0.49 & \pm 0.05 & \\
\hline
\end{tabular}

*Significant difference as compared to control, **Significant difference as compared to paracetamol

\section{Discussions}

Ethanol extraction of the homogenized dried cloves of A. sativum and A. barbadensis gave a relatively low percentage yield, 6.8 and $11.8 \%$ respectively. This may suggest that most of the chemical components of the plants have low solubility in ethanol (Table 1). This could explain the use of aqueous extract of most medicinal plants by traditional medicine practitioners for the sole purpose of achieving high yield and potency as documented by [11].

Paracetamol induced oxidative stress and hepatotoxicity in all the treated animals, as reflected by significant increase $(\mathrm{p}<0.05)$ in AST, ALT, ALP and Bilirubin levels (Table 2) and a significant decrease ( $<$ < 0.05 ) in serum proteins levels (Table 3). This analgesic and antipyretic drug (paracetamol) is quite safe at therapeutic doses and normally undergoes glucuronidation and sulfation to the corresponding conjugates. When acetaminophen intake far exceeds therapeutic doses, the glucuronidation and sulfation pathways are saturated and the cytochrome P 450 pathways become increasingly important. However, with time hepatic glutathione is depleted faster than it can be regenerated and accumulation of a reactive and toxic metabolite occurs. In the absence of intracellular antioxidants such as glutathione, this reactive metabolite ( $\mathrm{N}$ - acetyl-P- benzoquinone imines, NAPQI) reacts with nucleophilic groups present on cellular macromolecules such as protein or lipids and alters the homeostasis of calcium resulting in hepatotoxicity [9].

The significant increase $(\mathrm{p}<0.05)$ in glutathione level observed after treatment of animals with extracts of A. sativum and A. barbadensis suggests hepatoprotection. The actual mechanism of hepatoprotection of these extracts is not well understood; however chemical constituents of plant extracts have been shown to exhibit antioxidant properties. For example, flavonoids have been reported to contain antioxidant properties [7]. These antioxidant properties of extracts may have contributed to hepatoprotection displayed in this work. Further, cells have a number of mechanisms to protect themselves from the toxic effect of reactive

oxygen species (ROS). Glutathione is an intracellular reductant, widely distributed in cells and plays major role in catalysis, metabolism and transport [3]. It protects cells against free radicals, peroxides and other toxic compounds [5]. In the present study, the effectiveness of these extracts was demonstrated using paracetamol induced rats which are a known model for both hepatic glutathione depletion and injury. Therefore, the level of glutathione is of crucial importance in liver injury caused by paracetamol. These results are in line with a research work by [7], because we found that after A. sativum and A. barbadensis administration, the GSH level increased significantly $(\mathrm{p}<0.05)$ in a dose dependent manner as compared with paracetamol treated showing that the extracts may contain principles that might provide a means to recover reduced GSH levels and to prevent tissue disorders and injuries [12]

The significant increase $(\mathrm{p}<0.05)$ in AST and ALT levels in rats treated with paracetamol overdose show that the paracetamol affected the liver cells causing the enzymes to leak into circulation. However, treatment with ethanolic extract of A. sativum and A. barbadensis caused a significant decrease $(\mathrm{p}<0.05)$ in the elevated levels of AST and ALT in a dose dependent order, showing that the extracts contains compounds that can be useful in the treatment of liver damage. Serum transaminases are important liver enzymes because they indicate the condition of the liver [12]. Liver degeneration due to drug toxicity is accompanied by leakage of liver enzymes from injured hepatocytes into circulation. These transaminases are most useful for monitoring the 
degree of recovery of a damaged liver [12]. This is in line with the work of [15], where the extent of liver damage property of A. barbadensis was observed in streptozotocin - induced diabetes in rats.

The results demonstrated that the ethanol extracts of A. sativum and A. barbadensis caused significant inhibition $(\mathrm{p}<0.05)$ in the activity of serum alkaline phosphatase in rats treated with paracetamol overdose in a dose dependent manner. Alkaline phosphatase is another liver marker enzyme that is used to check liver dysfunction. Serum ALP and bilirubin levels are related to the function of hepatic cell. Increase in serum level of ALP is due to increased synthesis, in the presence of increasing biliary pressure [15].

Also a significant increase $(\mathrm{p}<0.05)$ was observed in bilirubin level in rats treated with paracetamol overdose as compared with the control group. This decreased significantly $(\mathrm{p}<0.05)$ on administration of extracts. From the results obtained, the extracts were more effective at the highest concentration of $800 \mu \mathrm{g} / \mathrm{ml}$. Effective control of alkaline phosphatase activity and bilirubin level points towards an early improvement in secretory mechanism of hepatic cells [3-8].

The extracts of A. sativum and A.barbadensis produced a significant increase $(\mathrm{p}<0.05)$ in albumin level in the groups; these effects were found to be dose dependent. The reversal of this hypoalbuminaemia by the extract is currently poorly understood. However, albumin performs an important function in binding many substances, reducing their availability and toxic actions. Thus, the binding (conjugation) of bilirubin protects the newborn child against the toxic action of the substance, preventing it from penetrating the blood-brain-barrier [9]. The binding ability of albumin to drugs is reduced in hypoalbuminaemia when binding sites are blocked by various metabolites. Although these hepatoprotection can not be ascribed to a particular chemical constituent of the extracts, some of their phytochemicals such as flavonoids and phenols are known to poses antioxidant properties.

Therefore, it seems logical to infer that ethanolic extracts of A. sativum and A.barbadensis have antioxidant property and might be capable of protecting the hepatic tissue from paracetamol induced injury and inflammatory changes.

In summary, the results have demonstrated that overdose of paracetamol intake $(500 \mathrm{mg} / \mathrm{kg}$ body weight) could be dangerous to the liver. From the findings, the ethanol extracts of A. sativum and A. barbadensis had dose dependent effects on the parameters analyzed, hence their use as antioxidants and hepatoprotective agents may have bases.

In conclusion, this research work has shown the damaging effects of paracetamol overdose and that the medicinal plant $A$. sativum and A. barbadensis posses high antioxidant activity which can enhance the body defense mechanism in conditions of oxidative stress and also a hepatoprotective activity which can rid the liver of toxic metabolites.

Further studies regarding the isolation and characterization of the active principles responsible for the antioxidant and hepatoprotective activity of these medicinal plants is recommended. Partial purification of the extracts is also recommended.

[1] Benzie, I.F. (1996). Lipid peroxidation Review of Causes, Consequences, Measurement and Dietary influences. International journal offood science and Nutrition, 72 (3): 211 - 230.

[2] Chen, Y. (2007). Hepatocyte Specific GSH Deletation leads to Rapid Onset of Steatosis. Journal of Hepatology 45 (2): 1118 - 20.

[3] Chen, Y. (2007). Hepatocyte Specific GSH Deletation leads to Rapid Onset of Steatosis. Journal of Hepatology 45 (2): 1118 - 20.

[4] Collins, H.O.E; Ndubisi, B.D. and Iyamu, H. (2003). Nature's Greatest Revelations $1^{\text {st }}$ Edition, Lay Apostolate Publications, P $3-5$.

[5] Ellman, G.L. (1958). Tissue Sulphydryl Groups. Journal of Biochemistry and Biophysics 82 (2): $70-77$.

[6] Fairhust, S; Barber, D.J; Clark, B. and Horton, A.A. (1982). Studies on Paracetamol induced Lipid Peroxidation. Toxicology 23(2): 136-139.

[7] Ghosh, T; Kumar, T; Das, M; Bose, A. and Kumar, D. (2007). In Vitro Antioxidant and Hepatoprotective Activity of Ethanolic Extract of Bacopa monnieri Linn. Aerial Parts. Iranian Journal of Pharmacology and Forms Journal of plant cell physiology 47 (7): 984-94.

[8] Halliwell, B. (1987). Oxidants and Human Diseases, some new concepts. Medical Journal 2(1): $358-364$

[9] Katzung, B. (1998). Basic and Clinical Pharmacology, 7th Edition, Mc Graw-Hill, Appleton and Lange, p.50-60.

[10] Low-Dog, T; Rile, B. and Carter, T. (2001). Traditional and Alternative Therapies for Breast Cancer. Alternative Therapy 7(3); 36-47.

[11] Malloy, H.T. and Evelyn, K.A. (1937). The Determination of Bilirubin with the Photometric Colorimeter. Journal of Biological Chemistry $119(2): 277-221$

[12] Nelson, D.L. and Cox, M.M. (2000). Lehninger, Principles of Biochemistry, $3^{\text {rd }}$ Edition,

[13] Onuegbu, M.A. (2000). Aloe Vera, and the Uses of Aloe Vera, 1st Edition, lay Apostolate publications, p.1-5

[14] Sofowora, E.A. (1993). Photochemical Screening of Nigerian Medicinal Plants part, Lloydia press. P. 234. Therapeutics, 6 (1): $77-85$.

[15] Tietz, N. W. (2000). Fundamental of Clinical Chemistry. W.B.Saunders Company, London 102-162.

[16] Vermeulen, N.P.E; Bassems, J. G. and Van De streat, R. (1992). Molecular Aspects of Paracetamol - induced Hepatotoxicity and its Mechanism Based Prevention. Journal of Drug Metabolism Review 24 (4): 267-307.

[17] Vutyavanich, T; Kraisarin, T. and Ruangsr, R. (2001). Ginger for Nausea and Vomiting in Pregnancy Randomized double Masked Placebo Controlled Trial. Journal of Obstetrics Gynecology 97 (4): 577-582

[18] Yoshiki, Y. and Okubo, K. (1995). Active Oxygen Scavenging Activity of DDMP (2, 3, Dihydro -2-5- dihydroxy- 6- methyl 4Hpyran- 4- one) saponin in Soybean Seed. Journal of Bioscience, Biotechnology and Biochemistry 59 (6): 1556 - 1557. 